\title{
Influence of organic manure, Minia Azotein, mycorrhizae fungi and active yeast application on growth and chemical constituents of Taxodium distichum seedlings
}

\author{
Ali A. F. ${ }^{a^{*}}$, Ahmed A. A. ${ }^{b}$, Abd El-Raheem A. Sh. ${ }^{a}$ \\ ${ }^{a}$ Horticulture Department, Faculty of Agriculture, Al-Azhar University, Assiut, Egypt \\ ${ }^{b}$ Horticulture Research Institute, Agricultural Research Center, Giza, Egypt
}

\begin{abstract}
This research was conducted during the two consecutive seasons of 2017/2018 and 2018/2019 to study the effect of Filter mud as organic manure and biofertilizers application, as well as, their interaction on growth and some chemical constituents of baldcypress (Taxodium distichum) seedlings. Filter mud was applied at 0 , 24, 48, and $72 \mathrm{~g} / \mathrm{bag}$. Biofertilizers were control, Active Yeast (AY), Minia Azotein (M.A.), Arbescular mycorrhizea fungi (AM), AY+ M.A., AY+AM, M.A.+AM and AY+M.A.+AM. The most obtained results were as follows: The addition of filter mud at all levels led to a significant increase in plant growth traits (stem length, stem diameter, leaves fresh and dry weights /plant and stem fresh and dry weights /plant, as well as, the elements of $\mathrm{N}, \mathrm{P}$ and $\mathrm{K} \%$ in the leaves), as compared to the check treatment. Utilizing the high level of filter mud $(72 \mathrm{~g} / \mathrm{bag})$ registered the highest values of these parameters. In relation to biofertilizers treatments, all of them either separately or in combination, except for active yeast, in some cases, led to a significant augment in these previous traits. The application of triple inoculants (AY+ M.A. +AM) proved to be more effective in increasing these above mentioned parameters. In addition, for the interaction, it was significant effect on all examined characters, except for stem diameter. Clearly, most of combined treatments significantly increased all studied traits comparing to untreated ones. The most effective treatments were detected by using filter mud at the high level with the triple inoculants (AY+ M.A. +AM) in comparison with those obtained by other combination treatments.
\end{abstract}




\section{Introduction}

Baldcypress (Taxodium distichum) is a native and deciduous conifer. It is one of the most famous conifer trees because it's economic and ecological importance, as well as, it's highly tolerant to flooding and logging of soil water (Allen et al., 1996; Larzen, 1980; Wilhite and Toliver, 1990). It belongs to family Taxodiaceae which contains 10 genera and 16 species of cone bearing trees native to North America, Asia and Tasmania. The leaves and seeds of Taxodium distichum L. Rich. have been used for the treatment of malaria and liver diseases (Sharaf, 1928) and the resins obtained from its cones are used as an analgesic for skin ailments. The essential oil isolated from the female cones is anti-inflammatory and antispasmodic effects, as well as, antibacterial and antifungal activities (ElTantawy et al., 1999). The wood of Taxodium is durable and highly resistant to decay, making it valuable for multiple of uses viz. building construction, fine furniture, planking in boats, doors, floorings and cabinetry (Collingwood 1937 and Walker, 1990). Nowadays, organic agriculture is become a fermentative alternative to chemical fertilizers because organic manures are very save for human, animal and environment. Follet et al. (1981) suggested the positive roles of organic manure for example: Improve soil properties, water holding capacity and accelerate releasing essential nutrients by microbial decomposition. Filter mud as a local organic fertilizer, it's very beneficial in enhancing the plant growth and productivity. Organic manures contain growth promoting hormones i.e. IAA and GA, macronutrients, essential micronutrients and beneficial microorganisms (Natarajan, 2007; Sreenivasa et al., 2010). The promotion effect of organic manure on improving the growth and some chemical constituents was studied by Ali et al. (2001) and El-Sayed and Abdou (2002) on Khaya senegalensis, Ahmadloo et al. (2012) on cypress seedlings, Abdou et al. (2007) on Ficus elastica var. Decora Mahmmoud (2014) on Populus nigra and Abou El-Makarem (2016), Abdel-Salam (2017) and Hussein (2019) on moringa. Biofirtilizers (microbial inoculants) act an important role in improving soil fertility by increasing number of microorganisms and accelerate certain microbial processes in rhizosphere zone. Such microbiological processes can convert the nutrients from the forms of unavailable to available ones (Alaa El-Din, 1982; Rao, 1981). Minia Azotein as biofertilizer containing different strains of $\mathrm{N}$-fixing bacteria. These bacteria capable produce some plant growth hormones (IAA, GA3), thiamin, riboflavin and nicotin (Hartmann et al., 1983; Tien et al., 1979). Phosphate dissolving organisms including mycorrhizae fungi which play an important role on plant growth and chemical constituent traits by production some of growth promotion namely auxins, GA3 and cytokinins, producing phosphate enzymes which are converting organic phosphate to mineral-P which it is possible to absorb by plant, promoting influence on elements absorption $(\mathrm{N}, \mathrm{S}$, $\mathrm{Zn}, \mathrm{Mn}, \mathrm{Ca}$ and $\mathrm{Cu}$ ), protection plant from some diseases and augmenting the immunity against the diseases by 
increasing root cortex thickness (Read et al., 1991; Tate, 2001). The positive effect of biofertilizers (N-fixing bacteria and phosphate dissolving organisms) on enhancing the growth and chemical constituent characters was reported by ElSayed and Abdou (2002), Abdou et al. (2006) and Ali et al. (2015) on Khaya senegalensis, Abdou et al. (2004) and Pindi (2011) on Albizzia lebbek, ElKhateeb et al. (2010) on Chamaedorea elegans, Ahmed et al, (2005) and Mahmmoud (2014) on Populus nigra, Abou El-Khair (1993) on Casuarina glauca and Acacia saligna, Ahmed and Ali (2002) on Dalbergia sisso and Prosopis juliflora and Abou El-Makarem (2016), Abdel- Salam (2017) and Hussein (2019) on moringa. Active yeast (Saccharomyces cerveace) extract is considered as a good source of many natural growth substances (cytokinins), most nutritional elements ( $\mathrm{P}, \mathrm{K}, \mathrm{S}, \mathrm{N}, \mathrm{Ca}$ and $\mathrm{Mg}$ ), a lot of vitamin $\mathrm{B}$ and organic compounds i.e. proteins, lipids, carbohydrates and nucleic acids (Nagodawithana, 1991). The enhancement in plant growth and some chemical constituent traits due to applying active yeast was obtained by Ahmed et al. (1997) and Akl et al. (1997) on grape vine, Ahmed et al. (1998) on roselle, Ali (2001) on Calendula officinalis, Ahmed et al. (2001) on Ambrosia maritima, Ahmed (2002) on Leucaena leucocephala and Ahmed (2014) on Ceiba pentandra. The present work was intended to explore the influence of filter mud as organic manure, Minia Azotein. Mycorrhizae fungi and active yeast, as well as, their interaction on growth and some chemical constituents of baldcypress (Taxodium distichum) seedlings.

\section{Materials and methods}

This study was conducted during the two successive seasons of 2017/2018 and 2018/2019 at Monshaat Al-Amary, Luxor Governorate, Egypt to examine the influence of organic manure (filter mud) and biofertilization treatments (Minia Azotein, mycorrhizal fungi and active dry yeast), as well as, their interaction on plant growth and chemical constituent parameters of baldcypress (Taxodium distichum) seedlings. Baldcypress (Taxodium distichum) seedlings were obtained From Horticulture Research Institute, Giza, Egypt. One-year-old of baldcypress seedlings were planted on February $10^{\text {th }}$ for the two seasons in poly ethane bags of $20 \times 30 \mathrm{~cm}$. The seedlings were healthy and uniform, average seedling length was $20-23 \mathrm{~cm}$. and seedling diameter was $0.35-0.39 \mathrm{~cm}$. for both seasons, respectively. Each bag was filled with $10 \mathrm{~kg}$ of a mixture of sand + clay 2:1 (v:v) and contained one seedling. Chemical properties of the experimental soil were determined according to Jackson (1973) and are show in Table (1). The experimental design of this work was a split plot with four replications and five seedlings / replicate, filter mud treatments at four levels of $0,24,48$ and $72 \mathrm{~g} / \mathrm{bag}$ were considered as the main plots (A) and the eight biofertilization treatments occupied 
the sub-plot $(\mathrm{B})$, therefore the interaction treatments $(\mathrm{A} \times \mathrm{B})$ were 32 treatments. Filter mud as organic fertilizer was obtained from Sugar Factory, Armant, Luxor Governorate, Egypt and added with the soil before transplanting the seedlings. Chemical properties of filter mud used were estimated according to Black et al. (1965) and are listed in Table (2). Biofertilization treatments were control (Uninoculated seedlings), Active Yeast (AY), Minia Azotein (M.A.), Arbescular mycorrhizae fungi (AM), AY+M.A., AY+AM, M.A.+AM and AY+M.A.+AM. Minia Azotein (M.A.) contains $\mathrm{N}$-fixing bacteria (1ml M.A. contains $10^{7}$ cells) was added twice as soil drench around each seedling at $50 \mathrm{ml}$ /bag at one month interval starting March $7^{\text {th }}$ in both seasons, then seedlings were irrigated immediately. Arbescular mycorrhizae fungi (AM fungi) [Glomus mosseae NRC31 and Glomus fasciculatum NRC15] 275 spores/g media " peat, vermiculite and perlite was applied once at $3 \mathrm{~g} /$ seedling via touch seedling root during transplanting the seedlings. This mycorrhizal inoculum originally isolated from Egyptian soils and multiply on peat: vermiculite: perlite (Badr El-Din et al., 1999). Both of Minia Azotein and Arbescular mycorrhizae fungi were obtained from Biofertilization Unit, Agricultural Research Center, Giza. The application of active yeast $(5 \mathrm{~g} / \mathrm{l}$.) was used as foliar spray at three times at two weeks interval starting March $14^{\text {th }}$ in both seasons. All other agricultural practices were followed as usual. At the end of the experiment (the last week of January) of each season, the following data were recorded: stem length, stem diameter, leaves fresh and dry weight / plant and stem fresh and dry weight / plant. The studied elements of N, P and $\mathrm{K} \%$ were determined in the dried leaves as follows: Nitrogen (\%) was estimated according to the method of modified micro Kjeldahl as described by Wilde $e t$ al. (1985), Phosphorus (\%) was estimated colorimetrcally according to Chapman and Pratt (1975) and Potassium (\%) was determined by Flam photometer according to Cottenie et al. (1982). The data were tabulated and statistically analyzed according to MSTATE-C (1986) using the L.S.D test at $5 \%$ according to Gomez and Gomez (1984).

Table (1): Chemical properties of the used soil (average of the both seasons).

\begin{tabular}{|c|c|c|c|c|c|c|c|c|c|c|c|c|c|}
\hline \multirow{2}{*}{ 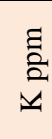 } & \multirow{2}{*}{ 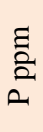 } & \multirow{2}{*}{$\begin{array}{l}\tilde{Z} \\
\text { Z } \\
\text { Z }\end{array}$} & \multicolumn{8}{|c|}{ Cations and anions (meq/l) } & \multirow{2}{*}{$\begin{array}{l}\delta^{\circ} \\
0 \\
0 \\
0 \\
ن\end{array}$} & & \multirow{2}{*}{$\overrightarrow{2}$} \\
\hline & & & $\mathrm{K}$ & $\mathrm{Na}$ & $\mathrm{Mg}$ & $\mathrm{Ca}$ & $\mathrm{SO}_{4}$ & $\mathrm{Cl}$ & $\mathrm{HCO}_{3}$ & $\mathrm{CO}_{3}$ & & & \\
\hline 47 & 15 & 10 & 0.6 & 1.2 & 0.2 & 0.2 & 0.0 & 1.2 & 1 & - & 10.7 & 0.58 & 7. \\
\hline
\end{tabular}


Table (2): Chemical properties of the used Filter mud (average of the both seasons).

\begin{tabular}{|c|c|c|c|c|c|c|c|c|c|c|c|c|}
\hline \multirow[b]{2}{*}{ Properties } & \multirow[b]{2}{*}{$\stackrel{T}{2}$} & \multirow{2}{*}{$\sum_{0}^{0}$} & \multicolumn{3}{|c|}{ Total } & \multirow[b]{2}{*}{$\begin{array}{l}\delta^{\circ} \\
\text { Uj }\end{array}$} & \multicolumn{4}{|c|}{ Total } & \multirow{2}{*}{ 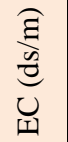 } & \multirow[b]{2}{*}{ Z } \\
\hline & & & $\mathrm{N} \%$ & $\mathrm{P} \%$ & $\mathrm{~K} \%$ & & $\begin{array}{c}\mathrm{Fe} \\
\mathrm{ppm}\end{array}$ & $\begin{array}{l}\mathrm{Mn} \\
\mathrm{ppm}\end{array}$ & $\begin{array}{c}\mathrm{Zn} \\
\mathrm{ppm}\end{array}$ & $\begin{array}{c}\mathrm{Cu} \\
\mathrm{ppm}\end{array}$ & & \\
\hline Values & 6.2 & 72.5 & 2.65 & 2.1 & 0.66 & 2.8 & 5000 & 323 & 102 & 180 & 4.72 & $18: 25$ \\
\hline
\end{tabular}

\section{Results and Discussion}

\subsection{Stem length $(\mathrm{cm})$}

The obtained results in Table (3) indicated that stem length of Taxodium distichum seedlings was significantly increased due to the application of filter mud as organic manure at all levels, during the two experimental seasons, as compared to the check treatment. Obviously, with increasing the level of filter mud stem length was significantly augmented in both seasons. Therefore, the longest plants were detected by using filter mud at the high level $(72 \mathrm{~g} / \mathrm{bag})$ as ranged 28.8 and $42.6 \%$ over unfertilized plants, during the two growing seasons, respectively. The role of organic manure in increasing stem length was also discussed by Ali et al. (2001), El-Sayed and Abdou (2002) on Khaya senegalensis, Ali et al. (2002), Ahmed et al. (2006) and Mahmmoud (2014) on Populus nigra and Siraji et al. (2001), Abdou et al. (2004), El-Khateeb et al. (2006), Abdou et al. (2007) and Saleh (2000) on Ficus spp. As for biofertilization treatments the data in Table (3) revealed that the use of them either separately or in combinations, except for active dry yeast, during the two seasons, led to a significant increase in stem length of baldcypress, comparing to untreated ones. The combined treatments either double or triple inoculants gave better results than alone inoculant ones, in both seasons. In this connection, supplying active yeast + Minia Azotein + mycorrhizae fungi gave the longest stems reached 23.3 and $22.4 \%$ over uninoculated plants in the first and second seasons, respectively. The efficiency of applying biofertilizers on enhancing stem length was also reported by El-Sayed and Abdou (2002), Abdou et al. (2006) and Ali et al. (2015) on Khaya senegalensis Ahmed and Ali (2002) and Dash et al. (2013) on Dalbergia spp. and Ahmed et al. (2005) and Mahmmoud (2014) on Poplar trees and Sudhakar et al. (2000) on Morus alba and Moustafa (2008) on Chorisia speciosa Abdou and Ashour (2012) on jojoba seedlings for N-fixing bacteria. Munro et al. (1999), Badram et al. (2003), Sarr et al. (2005), Ndiaye et al. (2011) and Ndoye et al. (2013) on Acacia spp. Abdou et al. (2007), El- Tayeb and El-Sayed (2010) on Ficus spp., On Chamaedorea alagena, El-Khateeb et al. (2010) regading phosphate resolving bacteria. While, Ahmed (2002) on Leacaena leucocephala, Ahmed et al. (2001) on Ambrosia maritime and Ahmed et al. (1998) on roselle plant and Akl et 
al. (1997) on Red Roomy grape vine and Ahmed (2014) on ceiba pentandra, Ali (2001) Calendula officinalis concerning active yeast. In relation to the interaction effect between the two examined factors, it was significant on stem length of baldcypress, during the two consecutive seasons. Cleary, all comined treatments, except for 0 filter mud with active dry yeast and 0 filter mud plus Minia Azotein, caused a significant augment in stem length as compared to untreated plants , during the two seasons, However, the application of filter mud at the high level (72 g / pot) with active dry yeast + Minia Azotein + mycorrhizae fungi, in both seasons proved to be more effective in increasing stem length than those obtained by other combination treatments, as clearly shown in Table (3).

Table (3): The effect of filter mud and biofertilizers treatments on stem length (cm.) of Taxodium distichum seedlings during 2017/2018 and 2018/2019 seasons.

\begin{tabular}{|c|c|c|c|c|c|c|c|c|c|c|}
\hline \multirow{4}{*}{$\begin{array}{l}\text { Bio-fertilizers } \\
\text { treatments } \\
\text { (B) }\end{array}$} & \multicolumn{10}{|c|}{ Filter mud levels g/plant (A) } \\
\hline & \multirow{2}{*}{ Control } & \multicolumn{8}{|c|}{ Stem length $(\mathrm{cm})$} & \multirow{2}{*}{ Mean $(B)$} \\
\hline & & 24 & 48 & 72 & Mean (B) & Control & 24 & 48 & 72 & \\
\hline & \multicolumn{5}{|c|}{ First season } & \multicolumn{5}{|c|}{ Second season } \\
\hline Cont. & 38.8 & 42.4 & 44.3 & 46.4 & 43.0 & 40.0 & 43.7 & 48.1 & 52.3 & 46.0 \\
\hline AY & 39.9 & 43.3 & 44.7 & 48.3 & 44.0 & 40.3 & 44.5 & 47.8 & 53.7 & 46.6 \\
\hline M.A & 40.3 & 44.7 & 46.4 & 49.7 & 45.2 & 42.3 & 46.3 & 50.1 & 58.7 & 49.4 \\
\hline A.M & 42.3 & 44.5 & 49.1 & 54.3 & 47.5 & 44.6 & 45.7 & 52.3 & 65.1 & 51.9 \\
\hline AY+M.A & 41.8 & 44.3 & 46.9 & 52 & 46.2 & 43.8 & 47.2 & 50.9 & 59.1 & 50.3 \\
\hline AY+A.M & 42.8 & 45.7 & 50.3 & 56.7 & 48.9 & 45.1 & 47.7 & 54.3 & 67.6 & 53.7 \\
\hline M.A+A.M & 43.8 & 46.7 & 53.1 & 57.9 & 50.4 & 46.9 & 49.3 & 55.7 & 70.2 & 55.5 \\
\hline AY+M.A+A.M & 44.3 & 48.7 & 55.1 & 64.0 & 53.0 & 46.4 & 50.9 & 56.0 & 72.0 & 56.3 \\
\hline Mean (A) & 41.7 & 45.0 & 48.7 & 53.7 & & 43.7 & 46.9 & 51.9 & 62.3 & \\
\hline LSD $0.05 \%$ & \multicolumn{2}{|c|}{ A: 1.6} & B: 1.3 & \multicolumn{2}{|c|}{$\mathrm{AB}: 2.5$} & \multicolumn{2}{|c|}{ A: 1.3} & $\mathrm{~B}: 1.7$ & \multicolumn{2}{|c|}{$\mathrm{AB}: 3.3$} \\
\hline
\end{tabular}

Cont. $=$ Untreated plants, AY = Active yeast, M.A.= Minia Azotein, A.M = Arbescular mycorrhizae.

\subsection{Stem diameter $(\mathrm{cm})$}

The presented data in Table (4) cleared that fertilizing Taxodium distichum seedlings with filter mud at all levels, in both seasons, significantly increased stem diameter as compared to the check treatment. Obviously, there was a gradual, significant augment in such trait with increasing the level of filter mud during the two seasons. Therefore, the use of the high level of filter mud (72 g/ pot) registered thicker stems which increased it by 25.00 and by $28.81 \%$ over control plants during the two growing seasons, respectively. Many investigators came to similar results that organic manure treatments increased stem diameter in many plants such as Ali et al. (2001), El-Sayed and Abdou (2002) on Khaya senegalensis, and Abdou et al. (2008) and Abdou and Ashour (2012) on jojoba seedling and Ali et al. (2002), Ahmed et al. (2006) and Mahmmoud (2014) on Populus nigra and Abdou et al. (2004), El-Khateeb et al. (2006), 
Abdou et al. (2007) and Saleh (2000) on Ficus spp. In regard to biofertilizers application, the listed data in Table (4) showed that all used treatments either alone or mixed, except for active dry yeast, in both seasons, resulted a significant increase in stem diameter comparing to uninoculated ones. However, double or triple inoculant treatments were better than separately ones, in both seasons. In connection, triple inoculants (active yeast + Minia Azotein + mycorrhizae fungi) proved to be more effective in increasing stem diameter as ranged 27.27 and $26.22 \%$ over untreated plants, during the tow experimental seasons, respectively. The beneficial effect of biofertilizers on enhancing stem diameter could be explained through the findings of ElSayed and Abdou (2002), Abdou et al. (2006) and Ali et al. (2015) on Khaya senegalensis Ahmed and Ali (2002) and Dash et al. (2013) on Dalbergia spp. and
Ahmed et al. (2005) and Mahmmoud (2014) on Poplar trees and Sudhakar et al. (2000) on Morus alba and Moustafa (2008) on Chorisia speciosa Abdou and Ashour (2012) on jojoba seedlings, regarding $\mathrm{N}$-fixing bacteria, Al-Hadad et al. (2014) on Eucalyptus comaldulensis and Abdou et al. (2007), El-Tayeb and El-Sayed (2010) on Ficus spp. Also, Munro et al. (1999), Badran et al. (2003), Sarr et al. (2005), Ndiaye et al. (2011) and Ndoye et al. (2013) on Acacia spp., regarding phosphate resolving bacteria. While, Ahmed (2002) on Leacaena leucocephala, Ahmed et al. (2001) on Ambrosia maritime and Ahmed et al. (1998) on roselle plant and Akl et al. (1997) on Red Roomy grape vine and Ahmed (2014) on Ceiba pentandra, Ali (2001) Calendula officinalis for active yeast. Accordingly, the combination between the two examined factors on stem diameter, during the two seasons, had no significant effect (Table 4).

Table (4): The effect of filter mud and biofertilizers treatments on stem diameter (cm.) of Taxodium distichum seedlings during 2017/2018 and 2018/2019 seasons.

\begin{tabular}{|c|c|c|c|c|c|c|c|c|c|c|}
\hline \multirow{4}{*}{$\begin{array}{l}\text { Bio-fertilizers } \\
\text { treatments } \\
\text { (B) }\end{array}$} & \multicolumn{10}{|c|}{ Filter mud levels g/plant (A) } \\
\hline & \multirow[b]{2}{*}{ Control } & \multicolumn{8}{|c|}{ Stem diameter $(\mathrm{cm})$} & \multirow[b]{2}{*}{ Mean (B) } \\
\hline & & 24 & 48 & 72 & Mean (B) & Control & 24 & 48 & 72 & \\
\hline & \multicolumn{5}{|c|}{ First season } & \multicolumn{5}{|c|}{ Second season } \\
\hline Cont. & 0.50 & 0.53 & 0.55 & 0.63 & 0.55 & 0.53 & 0.61 & 0.62 & 0.69 & 0.61 \\
\hline AY & 0.51 & 0.53 & 0.57 & 0.61 & 0.55 & 0.53 & 0.6 & 0.65 & 0.69 & 0.62 \\
\hline M.A & 0.55 & 0.55 & 0.59 & 0.68 & 0.59 & 0.57 & 0.66 & 0.68 & 0.73 & 0.66 \\
\hline A.M & 0.57 & 0.59 & 0.68 & 0.73 & 0.64 & 0.60 & 0.66 & 0.72 & 0.76 & 0.68 \\
\hline AY+M.A & 0.55 & 0.58 & 0.61 & 0.68 & 0.6 & 0.60 & 0.65 & 0.67 & 0.74 & 0.66 \\
\hline AY+A.M & 0.59 & 0.61 & 0.71 & 0.72 & 0.66 & 0.62 & 0.69 & 0.73 & 0.78 & 0.70 \\
\hline M.A+A.M & 0.62 & 0.63 & 0.75 & 0.78 & 0.69 & 0.64 & 0.74 & 0.77 & 0.82 & 0.74 \\
\hline $\mathrm{AY}+\mathrm{M} \cdot \mathrm{A}+\mathrm{A} \cdot \mathrm{M}$ & 0.63 & 0.65 & 0.76 & 0.76 & 0.70 & 0.64 & 0.77 & 0.80 & 0.86 & 0.77 \\
\hline Mean (A) & 0.56 & 0.58 & 0.65 & 0.70 & & 0.59 & 0.67 & 0.70 & 0.76 & \\
\hline LSD $0.05 \%$ & \multicolumn{2}{|c|}{$\mathrm{A}: 0.02$} & B:0.03 & \multicolumn{2}{|c|}{ AB:n.s } & \multicolumn{2}{|c|}{ A:0.04 } & B:0.02 & \multicolumn{2}{|c|}{ AB: $n \cdot s$} \\
\hline
\end{tabular}

Cont $=$ Untreated plants, $\mathrm{AY}=$ Active yeast, $\mathrm{M} . \mathrm{A} .=$ Minia Azotein, $\mathrm{A} . \mathrm{M}=$ Arbescular mycorrhizae. 
Obviously most of combined treatments led to an increase in such parameter in comparison with those obtained by other combination treatments, in both seasons. The highest values were detected by applying filter mud at the high level (72 $\mathrm{g} / \mathrm{bag}$ ) in combination with active yeast + Minia Azotein + mycorrhizal fungi or filter mud at the high level with Minia Azotein plus mycorrhizal fungi, as compared to other combination treatments, during the two consecutive seasons, as clearly declared in Table (4).

\subsection{Leaves fresh weight ( $g$ )/plant}

As shown in Table (5) that leaves fresh weight /plant of Taxodium distichum was significantly increased as a result of supplying organic manure as filter mud at all levels, during the two growing seasons, comparing to unfertilized plants. Such parameter was gradual significantly augmented with increasing filter mud level, in both seasons. Therefore, the heaviest fresh weight of leaves was obtained by the application of filter mud at the high level (72 g / plant) which increased such trait by 77.6 and by 64.8 $\%$ over the check treatment in the first and second seasons, respectively. It worthy mention that inoculating Taxodium distichum seedlings with all biofertilizers either individually or together, in both seasons, resulted a significant augment in leaves fresh weight / plant, as compared to uninoculated treatments, except for active dry yeast, in the first season. Apparently, double or triple inoculant treatments gave better results than separately ones, during the two consecutive seasons. Clearly, the heaviest fresh weight of leaves / plant was observed when utilizing the triple inoculants (active yeast + Minia Azotein + mycorrhizal fungi) reached 64.8 and $51.4 \%$ over control plants, during the two experimental seasons, respectively, as clearly postulated in Table (5).

Table (5): The effect of filter mud and biofertilizers treatments on leaves fresh weight (g/plant) of Taxodium distichum seedlings during 2017/2018 and 2018/2019 seasons.

\begin{tabular}{|c|c|c|c|c|c|c|c|c|c|c|}
\hline \multirow{4}{*}{$\begin{array}{l}\text { Bio-fertilizers } \\
\text { treatments } \\
\text { (B) }\end{array}$} & \multicolumn{10}{|c|}{ Filter mud levels g/plant (A) } \\
\hline & \multirow{2}{*}{ Control } & \multicolumn{8}{|c|}{ Leaves fresh weight (g/plant) } & \multirow{2}{*}{ Mean $(B)$} \\
\hline & & 24 & 48 & 72 & Mean (B) & Control & 24 & 48 & 72 & \\
\hline & \multicolumn{5}{|c|}{ First season } & \multicolumn{5}{|c|}{ Second season } \\
\hline Cont. & 13.2 & 17.2 & 19.1 & 20.9 & 17.6 & 12.4 & 18.6 & 21.1 & 21.9 & 18.5 \\
\hline AY & 13.2 & 18.7 & 19.9 & 22.0 & 18.4 & 13.2 & 21.3 & 22.4 & 23.2 & 20.0 \\
\hline M.A & 14.3 & 20.2 & 23.8 & 24.3 & 20.6 & 15.5 & 22.0 & 24.3 & 24.7 & 21.6 \\
\hline A.M & 13.5 & 23.7 & 26.7 & 28.0 & 23.0 & 16.4 & 24.3 & 25.6 & 26.4 & 23.2 \\
\hline AY+M.A & 14.8 & 22.9 & 24.2 & 24.8 & 21.7 & 17.0 & 23.4 & 25.5 & 26.0 & 23.0 \\
\hline AY+A.M & 15.7 & 24.6 & 27.2 & 27.8 & 23.8 & 17.0 & 24.3 & 26.4 & 27.0 & 23.6 \\
\hline M.A+A.M & 18.1 & 27.0 & 30.9 & 33.0 & 27.2 & 18.3 & 28.7 & 30.2 & 32.0 & 27.3 \\
\hline AY+M.A+A.M & 18.7 & 28.6 & 33.5 & 35.0 & 29.0 & 19.4 & 29.3 & 30.8 & 32.4 & 28.0 \\
\hline Mean $(\mathrm{A})$ & 15.2 & 22.9 & 25.7 & 27.0 & & 16.2 & 24.0 & 25.8 & 26.7 & \\
\hline LSD $0.05 \%$ & \multicolumn{2}{|c|}{ A: 0.6} & B: 1.0 & \multicolumn{2}{|c|}{$\mathrm{AB}: 2.0$} & \multicolumn{2}{|c|}{$\mathrm{A}: 0.7$} & B:0.8 & \multicolumn{2}{|c|}{ AB: 1.6} \\
\hline
\end{tabular}

Cont. $=$ Untreated plants, $\mathrm{AY}=$ Active yeast, M.A.= Minia Azotein, A.M = Arbescular mycorrhizae. 
With respect to the interaction, given data in Table (5) pointed out that it was significant effect on leaves fresh weight / plant, during two growing seasons. The most of combined treatments led to a significant increase in leaves fresh weight / plant, during the two seasons, as compared to untreated ones. In connection, the application of filter mud at the high level (72 g / bag) with triple inoculants (active yeast + Minia Azotein + mycorrhizae fungi) proved to be more effective in increasing such trait than those obtained by other combination treatments, during the two growing seasons.

\subsection{Leaves dry weight (g) /plant}

The revealed data in Table (6) indicated that the obtained values of leaves dry weight / plant of Taxodium distichum seedlings had a trend similar to those of leaves fresh weight / plant in the two experimental seasons. Apparently, receiving the seedlings filter mud as organic manure at all levels, in both seasons, significantly increased in leaves dry weight / plant comparing to the check treatment. Such parameter was gradual significantly augmented with increasing the level of filter mud during the two seasons. Therefore, the high level of filter mud (72 g / plant) resulted the heaviest leaves dry weight / plant as ranged 80.0 and $68.4 \%$ over unfertilized plants, in both seasons, respectively. The capability of organic manure on increasing leaves weight was also demonstrated by Ali et al. (2001), El-Sayed and Abdou (2002) on Khaya senegalensis, and Ali et al. (2002), Ahmed et al. (2006) and Mahmmoud
(2014) on Populus nigra and Siraji et al. (2001), Abdou et al. (2004), El-Khateeb et al. (2006), Abdou et al. (2007) and Saleh (2000) on Ficus Spp. And Badran et al. (2003) on Acacia saligna and Abdou and Ashour (2012) on jojoba seedling. It is evident from the obtained results that the inoculation with active yeast, Minia Azotein and mycorrhizae fungi either alone or in combinations caused a significantly increase in leaves dry weight /plant, as compared to uninoculated ones, during the two consecutive seasons. It is clear that the use of double or triple inoculants application recorded better results than alone applied for the two seasons. Obviously, triple inoculants (active yeast + Minia Azotein + mycorrhizae fungi) proved to be more effective in augmenting such parameter than those obtained by other treatments for both seasons. Such superior previous treatment increased leaves dry weight / plant by 65.8 and by $53.5 \%$ over control plants, in the first and second seasons, respectively, as clearly indicated in Table (6). The enhancement in leaves weight due to using biofertilizers was also insured by El-Sayed and Abdou (2002), Abdou et al. (2006) and Ali et al. (2015) on Khaya senegalensis and Ahmed et al. (2005) and Mahmmoud (2014) on Poplar trees and Moustafa (2008) on Chorisia speciosa Abdou and Ashour (2012) on jojoba seedlings, Ahmed and Ali (2002) and Dash et al. (2013) on Dalbergia spp concerning N-fixing bacteria. Abou ElKhair (1993) and Munro et al. (1999), Badran et al. (2003), Sarr et al. (2005), Ndiaye et al. (2011) and Ndoye et al. (2013) on Acacia spp. and Abdou et al. (2007), El-Tayeb and El-Sayed (2010) on 
Ficus spp. and Abdou et al. (2003), Meenakshisundaram et al. (2011) and Soliman et al. (2015) on Delonix regia for phosphate resolving bacteria. Whereas, Ahmed (2002) on Leacaena leucocephala, and Ahmed et al. (1998) on roselle plant and Akl et al. (1997) on Red Roomy grape vine and Ahmed (2014) on Ceiba pentandra, Ali (2001) Calendula officinalis regarding active yeast. Concerning the interaction, the presented results in Table (6) proved that it was significant effect on leaves dry weight / plant of Taxodium distichum, during the two experimental seasons. Clearly, such trait was significantly augmented, in both seasons, due to applying most of combined treatments, as compared to untreated plants. However, the addition of filter mud at the high level (72 $\mathrm{g}$ /plant) with triple inoculants (active yeast + Minia Azotein + mycorrhizae fungi) proved to be more effective in increasing leaves dry weight / plant than those obtained by other combination treatments for the two growing seasons.

Table (6): The effect of filter mud and biofertilizers treatments on leaves dry weight (g/plant) of Taxodium distichum seedlings during 2017/2018 and 2018/2019 seasons.

\begin{tabular}{|c|c|c|c|c|c|c|c|c|c|c|}
\hline \multirow{4}{*}{$\begin{array}{l}\text { Bio-fertilizers } \\
\text { treatments } \\
\text { (B) }\end{array}$} & \multicolumn{10}{|c|}{ Filter mud levels g/plant (A) } \\
\hline & \multirow{2}{*}{ Control } & \multicolumn{8}{|c|}{ Leaves dry weight (g/plant) } & \multirow{2}{*}{ Mean $(B)$} \\
\hline & & 24 & 48 & 72 & Mean (B) & Control & 24 & 48 & 72 & \\
\hline & \multicolumn{5}{|c|}{ First season } & \multicolumn{5}{|c|}{ Second season } \\
\hline Cont. & 3.1 & 4.1 & 4.5 & 5.0 & 4.1 & 2.9 & 4.4 & 5.0 & 5.2 & 4.4 \\
\hline AY & 3.1 & 4.4 & 4.7 & 5.0 & 4.3 & 3.1 & 4.8 & 5.3 & 6.2 & 4.8 \\
\hline M.A & 3.4 & 4.8 & 5.6 & 5.7 & 4.9 & 3.7 & 5.1 & 5.8 & 5.9 & 5.1 \\
\hline A.M & 3.2 & 5.6 & 6.3 & 6.5 & 5.4 & 3.8 & 5.7 & 6.0 & 6.3 & 5.4 \\
\hline $\mathrm{AY}+\mathrm{M} . \mathrm{A}$ & 3.4 & 5.4 & 5.8 & 5.9 & 5.1 & 4.0 & 5.5 & 6.0 & 6.2 & 5.4 \\
\hline $\mathrm{AY}+\mathrm{A} \cdot \mathrm{M}$ & 3.6 & 5.8 & 6.4 & 6.6 & 5.6 & 3.9 & 5.7 & 6.2 & 6.4 & 5.6 \\
\hline M.A+A.M & 4.3 & 6.5 & 7.3 & 7.7 & 6.4 & 4.3 & 6.9 & 7.2 & 7.6 & 6.5 \\
\hline AY+M.A+A.M & 4.3 & 6.7 & 7.9 & 8.2 & 6.8 & 4.5 & 6.9 & 7.3 & 7.7 & 6.6 \\
\hline Mean (A) & 3.5 & 5.4 & 6.1 & 6.3 & & 3.8 & 5.6 & 6.1 & 6.4 & \\
\hline LSD $0.05 \%$ & \multicolumn{2}{|c|}{ A: 0.2} & B:0.2 & \multicolumn{2}{|c|}{ AB: 0.4} & \multicolumn{2}{|c|}{$\mathrm{A}: 0.2$} & $\mathrm{~B}: 0$. & \multicolumn{2}{|c|}{$\mathrm{AB}: 0.5$} \\
\hline
\end{tabular}

Cont. $=$ Untreated plants, $\mathrm{AY}=$ Active yeast, M.A.= Minia Azotein, A.M = Arbescular mycorrhizae.

\subsection{Stem fresh weight $(g) /$ plant}

The illustrated data in Table (7) showed that supplying Taxodium distichum seedlings with filter mud at all levels, in both seasons, led to a significant increase in fresh weight of stem / plant comparing to control. By increasing the level of filter mud, such parameter was gradual significantly augmented, during the two growing seasons. Therefore, the heaviest fresh weight of stem / plant was obtained by using filter mud at the high level which increased it by 72.2 and by $60.0 \%$ over the check treatment, during the two seasons, respectively. In respect to biofertilizes application, the data in Table (7) indicated that there was a significant increase in stem fresh weight / plant, for the two seasons, due to the addition of all biofertilizers either separately or in combination, except for active dry yeast 
in the second season, as compared to uninoculated ones. Clearly, double or triple inoculants application achieved better results than individual ones, during the two consecutive seasons. However, applying triple inoculants (active yeast + Minia Azotein + mycorrhizae fungi) gave heavier stem fresh weight / plant as ranged 56.1 and $52.4 \%$ over untreated plants in the first and second seasons, respectively. Table (7) appeared that the combined effect between the two studied factors on stem fresh weight /plant was significant for the tow experimental seasons. Obviously, most of combined treatments, in both seasons, significantly increased stem fresh weight /plant comparing to untreated ones. In this concern, the application of filter mud at the high level in combination with triple inoculants (active yeast + Minia Azotein + mycorrhizae fungi) followed by the high level of filter mud plus the double inoculants (Minia Azotein + mycorrhizae fungi) proved to be more effective in increasing such trait than those obtained by other combination treatments, during the two experimental seasons.

Table (7): The effect of filter mud and biofertilizers treatments on stem fresh weight (g/plant) of Taxodium distichum seedlings during 2017/2018 and 2018/2019 seasons.

\begin{tabular}{|c|c|c|c|c|c|c|c|c|c|c|}
\hline \multirow{4}{*}{$\begin{array}{l}\text { Bio-fertilizers } \\
\text { treatments } \\
\text { (B) }\end{array}$} & \multicolumn{10}{|c|}{ Filter mud levels g/plant (A) } \\
\hline & \multirow{2}{*}{ Control } & \multicolumn{8}{|c|}{ Stem fresh weight (g/plant) } & \multirow{2}{*}{ Mean $(B)$} \\
\hline & & 24 & 48 & 72 & Mean (B) & Control & 24 & 48 & 72 & \\
\hline & \multicolumn{5}{|c|}{ First season } & \multicolumn{5}{|c|}{ Second season } \\
\hline Cont. & 7.7 & 9.2 & 10.3 & 12.1 & 9.8 & 8.0 & 9.0 & 11.8 & 13.3 & 10.5 \\
\hline AY & 7.8 & 9.3 & 11.1 & 12.3 & 10.1 & 8.0 & 9.0 & 12.3 & 13.7 & 10.8 \\
\hline M.A & 8.6 & 10.3 & 11.9 & 14.4 & 11.3 & 9.8 & 11.0 & 13.0 & 15.0 & 12.2 \\
\hline A.M & 8.1 & 10.7 & 14.1 & 16.1 & 12.3 & 9.8 & 12.1 & 14.6 & 15.8 & 13.1 \\
\hline AY+M.A & 8.5 & 10.4 & 13.5 & 14.7 & 11.8 & 10.0 & 11.3 & 14.1 & 15.5 & 12.7 \\
\hline $\mathrm{AY}+\mathrm{A} \cdot \mathrm{M}$ & 9.2 & 11.0 & 14.8 & 16.5 & 12.8 & 10.2 & 12.1 & 14.5 & 16.3 & 13.3 \\
\hline M.A+A.M & 10.7 & 13.6 & 16.5 & 18.8 & 14.9 & 11.3 & 13.7 & 17.2 & 19.0 & 15.3 \\
\hline AY+M.A+A.M & 11.2 & 13.9 & 17.0 & 19.2 & 15.3 & 12.6 & 14.3 & 17.6 & 19.5 & 16.0 \\
\hline Mean (A) & 9.0 & 11.0 & 13.6 & 15.5 & & 10.0 & 11.6 & 14.4 & 16.0 & \\
\hline LSD $0.05 \%$ & \multicolumn{5}{|c|}{ A:0.3 B:0.4 } & \multicolumn{2}{|r|}{$\mathrm{A}: 0.5$} & \multicolumn{3}{|c|}{ AB: 1.2} \\
\hline
\end{tabular}

Cont. $=$ Untreated plants, AY = Active yeast, M.A.= Minia Azotein, A.M = Arbescular mycorrhizae.

\subsection{Stem dry weight $(g) / p l a n t$}

Data in Table (8) emphasized that the obtained values of stem dry weight / plant had trend similar to those of stem fresh weight /plant for the two seasons. It is appeared that fertilizing Taxodium distichum seedlings with filter mud as organic manure at all levels, in both seasons, caused a significantly augment in stem dry weight /plant as compared to the check treatment. Obviously, there was a gradual, significant augment in such parameter with increasing the level of filter mud, during the two growing seasons. Morever, the use of filter mud at the high level ( $72 \mathrm{~g} /$ plant) registered the heaviest stem dry weight /plant which reached 77.5 and $65.9 \%$ over the unfertilized ones, for both seasons, 
respectively. The promotive influence of organic manures in augmenting stem weight was also detected by Ali et al. (2001), El-Sayed and Abdou (2002) on Khaya senegalensis, and Ali et al. (2002), Ahmed et al. (2006) and Mahmmoud (2014) on Populus nigra and Siraji et al. (2001), Abdou et al. (2004), El-Khateeb et al. (2006), Abdou et al. (2007) and Saleh (2000) on Ficus Spp. and Badran et al. (2003) on Acacia saligna. With respect to the application of biofertilizers, the obtained data in Table (8) indicated that inoculating Taxodium distichum seedlings with all examined inoculants, in both seasons, led to a significant increase in stem dry weight, except for active dry yeast, for the two seasons, comparing to uninoculated ones. It could be noticed that utilizing double or triple inoculants gave better results than separately ones, during the two consecutive seasons. Apparently, the addition of triple inoculants (active yeast + Minia Azotein + mycorrhizae fungi) proved to be more effective in increasing stem dry weight/ plant as ranged 55.5 and $52.0 \%$ over uninoculated plants, during the two growing seasons, respectively. The role of biofertilizers application on enhancing stem weight was also obtained by El-Sayed and Abdou (2002), Abdou et al. (2006) and Ali et al. (2015) on Khaya senegalensis, and Ahmed et al. (2005) and Mahmmoud (2014) on Poplar trees and Abdou and Ashour (2012) on jojoba seedlings, Ahmed and Ali (2002) and Dash et al. (2013) on Dalbergia spp., Moustafa (2008) on Chorisia speciosa and Abou El-Makarem (2016) and Abdel-Salam (2017) on Moringa oleifera regarding Nfixing bacteria Abo El-Khair (1993) and Munro et al. (1999), Badran et al. (2003), Sarr et al. (2005), on Acacia spp. and Abdou et al. (2007), El-Tayeb and ElSayed (2010) on Ficus spp. and Abdou et al. (2003), Meenakshisundaram et al. (2011) and Soliman et al. (2015) on Delonix regia for phosphate resolving bacteria.

Table (8): The effect of filter mud and biofertilizers treatments on stem dry weight (g/plant) of Taxodium distichum seedlings during 2017/2018 and 2018/2019 seasons.

\begin{tabular}{|c|c|c|c|c|c|c|c|c|c|c|}
\hline \multirow{4}{*}{$\begin{array}{l}\text { Bio-fertilizers } \\
\text { treatments } \\
\text { (B) }\end{array}$} & \multicolumn{10}{|c|}{ Filter mud levels g/plant (A) } \\
\hline & \multirow{2}{*}{ Control } & \multicolumn{8}{|c|}{ Stem dry weight (g/plant) } & \multirow{2}{*}{ Mean (B) } \\
\hline & & 24 & 48 & 72 & Mean (B) & Control & 24 & 48 & 72 & \\
\hline & \multicolumn{5}{|c|}{ First season } & \multicolumn{5}{|c|}{ Second season } \\
\hline Cont. & 3.5 & 4.1 & 4.7 & 5.6 & 4.5 & 3.6 & 4.1 & 5.4 & 6.0 & 4.8 \\
\hline $\mathrm{AY}$ & 3.5 & 4.2 & 5.0 & 5.6 & 4.6 & 3.6 & 4.1 & 5.6 & 6.2 & 4.9 \\
\hline M.A & 3.9 & 4.7 & 5.5 & 6.6 & 5.1 & 4.4 & 5.0 & 5.9 & 6.8 & 5.5 \\
\hline A.M & 3.6 & 4.9 & 6.4 & 7.4 & 5.6 & 4.4 & 5.5 & 6.6 & 7.2 & 5.9 \\
\hline AY+M.A & 3.8 & 4.7 & 6.1 & 6.8 & 5.3 & 4.5 & 5.1 & 6.4 & 7.1 & 5.8 \\
\hline AY+A.M & 4.1 & 5.0 & 6.8 & 7.6 & 5.9 & 4.6 & 5.5 & 6.8 & 7.4 & 6.1 \\
\hline M.A+A.M & 4.8 & 6.2 & 7.6 & 8.7 & 6.8 & 5.1 & 6.3 & 8.0 & 8.8 & 7.0 \\
\hline AY+M.A+A.M & 5.0 & 6.4 & 7.8 & 8.9 & 7.0 & 5.4 & 6.6 & 8.1 & 9.1 & 7.3 \\
\hline Mean (A) & 4.0 & 5.0 & 6.2 & 7.1 & & 4.4 & 5.2 & 6.6 & 7.3 & \\
\hline LSD $0.05 \%$ & \multicolumn{2}{|c|}{$\mathrm{A}: 0.2$} & B: 0.2 & \multicolumn{2}{|c|}{$\mathrm{AB}: 0.4$} & \multicolumn{2}{|c|}{$\mathrm{A}: 0.3$} & $\mathrm{~B}: 0.3$ & \multicolumn{2}{|c|}{ AB: 0.5} \\
\hline
\end{tabular}

Cont. $=$ Untreated plants, $\mathrm{AY}=$ Active yeast, M.A.= Minia Azotein, A.M = Arbescular mycorrhizae.

While, Ahmed (2002) on Leacaena leucocephala, Ahmed et al. (2001) on 
Ambrosia maritime and Ahmed et al. (1998) on roselle plant and Ahmed (2014) on Ceiba pentandra, Ali (2001) Calendula officinalis concerning active yeast. Regarding to the interaction between the two studied factors, it was significant effect on stem dry weight / plant during the two experimental seasons. Clearly, most of combined treatments, in both seasons, resulted a significant increase in stem dry weight / plant, as compared to untreated plants. However, the highest values of such parameter were detected when applying filter mud at the high level (72 g / bag) with triple inoculants (active yeast + Minia Azotein + mycorrhizal fungi) followed by filter mud at the high level with double inoculants (Minia Azotein + mycorrhizal) in comparison with those obtained by other combination treatments, during the two consecutive seasons, as clearly shown in Table (8).

\subsection{Nitrogen, phosphorus and potassium percentages}

The obtained results in Table (9) cleared that the utilization of filter mud as organic manure at all level, in both seasons, cased a significant augment in the three studied elements $\mathrm{N}, \mathrm{P}$ and $\mathrm{K} \%$ in the dried leaves of Taxodium distichum seedlings as compared to unfertilized ones. Obviously, significant differences among the levels of filter mud were detected, during the two seasons, except for between the low and moderate levels, regarding $\mathrm{P} \%$ in the first season and also between the moderate and high levels, in the second season, concerning $\mathrm{K} \%$. Apparently, using the high level of filter mud gave the highest values of $\mathrm{N}, \mathrm{P}$ and $\mathrm{K} \%$ as ranged 23.20 and $16.16 \%$ for $\mathrm{N} \%, 25.00$ and 17.76 for $\mathrm{P} \%$ and 21.73 and $31.13 \%$ for $\mathrm{K} \%$ over control plants, during the two seasons, respectively. The increase in the elements of $\mathrm{N}, \mathrm{P}$ and $\mathrm{K}$ as a result of supplying organic manure was also studied by Ali et al. (2001), El-Sayed and Abdou (2002) on Khaya senegalensis, and Ali et al. (2002), Ahmed et al. (2006) and Mahmmoud (2014) on Populus nigra and Abdou (2003) on Washingtonia filifera seedlings and Abdou et al. (2003) on Dalonix regia. As for biofertilizers application, the listed data Table (9) declared that inoculating Taxodium distichum seedlings with all examined biofertilizers, in both seasons, either separately or in mixture led to a significant increase in $\mathrm{N}, \mathrm{P}$ and $\mathrm{K} \%$, except for active dry yeast, during the two seasons, regarding the three elements $(\mathrm{N}$, $\mathrm{P}$ and $\mathrm{K} \%$ ), in addition to the treatment of double inoculants (active yeast + mycorrhizal fungi) concerning $\mathrm{N} \%$ in the second season, as compared to uninoculated ones. In most cases, applying double or triple inoculants gave better results for $\mathrm{N}, \mathrm{P}$ and $\mathrm{K} \%$ than those obtained by separately inoculants, during the two seasons. However, the highest values of $\mathrm{N}, \mathrm{P}$ and $\mathrm{K} \%$ were obtained by applying triple inoculants (active yeast + Minia Azotein + mycorrhizae fungi) and double inoculants (Minia Azotein + mycorrhizae fungi) reached $8.85,6.76$, 6.25 and $9.66 \%$ for $\mathrm{N} \%, 37.98,36.17$, 38.75 and $34.75 \%$ for $\mathrm{P} \%$ and 16.80 , $12.71,15.96$ and $13.55 \%$ for $\mathrm{K} \%$ as compared to uninculated plants, in the two seasons, respectively. The positive effect of applying biofertilizers on 
enhancing the elements of $\mathrm{N}, \mathrm{P}$ and $\mathrm{K}$ was also reported by Abdou et al. (2006), ElSayed and Abdou (2002) and Ali et al. (2015) on Khaya senegalensis, Abdou et al. (2004) on Albizzia lebbek, Ahmed et al. (2005) and Mahmmoud (2014) on poplar trees and Abou El-Makarem (2016) and Abdel-Salam (2017) on Moringa oleifera, Moustafa (2008) on
Chorisia speciosa for N-fixing bacteria. Abou El-Kheir (1993), Badran et al. (2003) and Sarr et al. (2005) on Acacia spp., El-Khateeb et al. (2010) on Chamaedorea elegans seedlings and Ali et al. (2014) Cassia acutifolia and Mohan and Radhakrishnan (2012) on Tectona grandis concerning phosphate resolving bacteria.

Table (9): The effect of filter mud and biofertilizers treatments on nitrogen percentage of Taxodium distichum seedlings during 2017/2018 and 2018/2019 seasons.

\begin{tabular}{|c|c|c|c|c|c|c|c|c|c|c|}
\hline \multirow{4}{*}{$\begin{array}{l}\text { Bio-fertilizers } \\
\text { treatments } \\
\text { (B) }\end{array}$} & \multicolumn{10}{|c|}{ Filter mud levels g/plant (A) } \\
\hline & \multirow{2}{*}{ Control } & \multicolumn{8}{|c|}{ Nitrogen $(\%)$} & \multirow{2}{*}{ Mean (B) } \\
\hline & & 24 & 48 & 72 & Mean (B) & Control & 24 & 48 & 72 & \\
\hline & \multicolumn{5}{|c|}{ First season } & \multicolumn{5}{|c|}{ Second season } \\
\hline Cont. & 1.75 & 1.86 & 1.96 & 2.11 & 1.92 & 1.93 & 1.99 & 2.18 & 2.18 & 2.07 \\
\hline $\mathrm{AY}$ & 1.75 & 1.83 & 1.98 & 2.14 & 1.92 & 1.90 & 1.98 & 2.14 & 2.21 & 2.06 \\
\hline M.A & 1.85 & 1.93 & 2.05 & 2.24 & 2.02 & 2.06 & 2.14 & 2.32 & 2.38 & 2.23 \\
\hline A.M & 1.78 & 1.84 & 2.05 & 2.17 & 1.96 & 1.93 & 2.06 & 2.16 & 2.32 & 2.12 \\
\hline AY+M.A & 1.86 & 1.96 & 2.15 & 2.24 & 2.05 & 2.02 & 2.16 & 2.25 & 2.40 & 2.21 \\
\hline $\mathrm{AY}+\mathrm{A} \cdot \mathrm{M}$ & 1.77 & 1.84 & 2.10 & 2.23 & 1.98 & 1.94 & 1.98 & 2.18 & 2.09 & 2.05 \\
\hline M.A+A.M & 1.83 & 1.88 & 2.12 & 2.33 & 2.04 & 2.16 & 2.18 & 2.32 & 2.43 & 2.27 \\
\hline AY+M.A+A.M & 1.88 & 1.93 & 2.18 & 2.37 & 2.09 & 1.90 & 2.20 & 2.34 & 2.40 & 2.21 \\
\hline Mean (A) & 1.81 & 1.88 & 2.07 & 2.23 & & 1.98 & 2.09 & 2.24 & 2.30 & \\
\hline LSD $0.05 \%$ & \multicolumn{2}{|l|}{ A. } & B:0.04 & \multicolumn{2}{|c|}{ AB: 0.07} & \multicolumn{2}{|c|}{$\mathrm{A}: 0.05$} & B:0.03 & \multicolumn{2}{|r|}{0.06} \\
\hline
\end{tabular}

Cont. $=$ Untreated plants, AY = Active yeast, M.A.= Minia Azotein, A.M = Arbescular mycorrhizae.

While, Ahmed (2002) on Leacaena leucocephala, Ahmed et al. (2001) on Ambrosia maritime and Ahmed et al. (1998) on roselle plant and Akl et al. (1997) on Red Roomy grape vine and Ahmed (2014) on ceiba pentandra, Ali (2001) Calendula officinalis regarding active yeast. The combined effect between the two examined factors was significant on $\mathrm{N}, \mathrm{P}$ and $\mathrm{K} \%$, during the two growing seasons. Applying most of combined treatments significant increased the three tested elements $(\mathrm{N}, \mathrm{P}$ and $\mathrm{K} \%)$ comparing to untreated ones, in both seasons. Clearly, the most effective treatments were obtained by using filter mud at the high level in combination with triple inoculants (active yeast + Minia Azotein + mycorrhizal fungi) and with double inoculants (Minia Azotein + mycorrhizal fungi) regarding $\mathrm{N}$ and $\mathrm{P} \%$, both seasons. While, applying filter mud at the moderate level with double inoculants (Minia Azotein) and filter mud at the high level plus triple inoculants (active yeast + Minia Azotein + mycorrhizal fungi) concerning $\mathrm{K} \%$ were the most effective treatments in both seasons, as clearly shown in Tables $(9,10$ and 11). 
Table (10): The effect of filter mud and biofertilizers treatments on phosphorus percentage of Taxodium distichum seedlings during 2017/2018 and 2018/2019 seasons.

\begin{tabular}{|c|c|c|c|c|c|c|c|c|c|c|}
\hline \multirow{4}{*}{$\begin{array}{l}\text { Bio-fertilizers } \\
\text { treatments } \\
\text { (B) }\end{array}$} & \multicolumn{10}{|c|}{ Filter mud levels g/plant (A) } \\
\hline & \multirow[b]{2}{*}{ Control } & \multicolumn{8}{|c|}{ Phosphorus (\%) } & \multirow{2}{*}{ Mean (B) } \\
\hline & & 24 & 48 & 72 & Mean $(\mathrm{B})$ & Control & 24 & 48 & 72 & \\
\hline & \multicolumn{5}{|c|}{ First season } & \multicolumn{5}{|c|}{ Second season } \\
\hline Cont. & 0.115 & 0.115 & 0.141 & 0.145 & 0.129 & 0.126 & 0.140 & 0.145 & 0.151 & 0.141 \\
\hline $\mathrm{AY}$ & 0.116 & 0.127 & 0.131 & 0.158 & 0.133 & 0.131 & 0.141 & 0.149 & 0.156 & 0.144 \\
\hline M.A & 0.140 & 0.141 & 0.151 & 0.165 & 0.149 & 0.138 & 0.154 & 0.160 & 0.168 & 0.155 \\
\hline A.M & 0.151 & 0.167 & 0.158 & 0.169 & 0.161 & 0.162 & 0.163 & 0.179 & 0.190 & 0.174 \\
\hline AY+M.A & 0.135 & 0.145 & 0.157 & 0.146 & 0.146 & 0.146 & 0.160 & 0.168 & 0.167 & 0.160 \\
\hline AY+A.M & 0.152 & 0.164 & 0.159 & 0.192 & 0.167 & 0.164 & 0.160 & 0.174 & 0.181 & 0.170 \\
\hline M.A+A.M & 0.157 & 0.175 & 0.170 & 0.213 & 0.179 & 0.177 & 0.180 & 0.195 & 0.208 & 0.190 \\
\hline $\mathrm{AY}+\mathrm{M} \cdot \mathrm{A}+\mathrm{A} \cdot \mathrm{M}$ & 0.155 & 0.171 & 0.174 & 0.210 & 0.178 & 0.174 & 0.182 & 0.199 & 0.212 & 0.192 \\
\hline Mean (A) & 0.140 & 0.151 & 0.155 & 0.175 & & 0.152 & 0.160 & 0.171 & 0.179 & \\
\hline LSD $0.05 \%$ & \multicolumn{2}{|c|}{ A:0.005 } & $: 0.005$ & \multicolumn{2}{|c|}{ AB: 0.010} & \multicolumn{2}{|c|}{ A:0.004 } & :0.004 & $\mathrm{AB}$ & 0.007 \\
\hline
\end{tabular}

Cont.$=$ Untreated plants, $\mathrm{AY}=$ Active yeast, $\mathrm{M} . \mathrm{A} .=$ Minia Azotein, $\mathrm{A} \cdot \mathrm{M}=$ Arbescular mycorrhizae .

Table (11): The effect of filter mud and biofertilizers treatments on potassium percentage of Taxodium distichum seedlings during 2017/2018 and 2018/2019 seasons.

\begin{tabular}{|c|c|c|c|c|c|c|c|c|c|c|}
\hline \multirow{4}{*}{$\begin{array}{l}\text { Bio-fertilizers } \\
\text { treatments } \\
\text { (B) }\end{array}$} & \multicolumn{10}{|c|}{ Filter mud levels g/plant (A) } \\
\hline & \multirow[b]{2}{*}{ Control } & \multicolumn{8}{|c|}{ Potassium $(\%)$} & \multirow[b]{2}{*}{ Mean (B) } \\
\hline & & 24 & 48 & 72 & Mean (B) & Control & 24 & 48 & 72 & \\
\hline & \multicolumn{5}{|c|}{ First season } & \multicolumn{5}{|c|}{ Second season } \\
\hline Cont. & 1.07 & 1.10 & 1.28 & 1.32 & 1.19 & 0.98 & 1.08 & 1.34 & 1.34 & 1.18 \\
\hline $\mathrm{AY}$ & 1.05 & 1.13 & 1.27 & 1.31 & 1.19 & 1.01 & 1.10 & 1.34 & 1.36 & 1.20 \\
\hline M.A & 1.08 & 1.16 & 1.27 & 1.41 & 1.23 & 1.03 & 1.21 & 1.38 & 1.36 & 1.25 \\
\hline A.M & 1.16 & 1.25 & 1.33 & 1.43 & 1.29 & 1.10 & 1.27 & 1.36 & 1.40 & 1.28 \\
\hline AY+M.A & 1.18 & 1.17 & 1.33 & 1.31 & 1.24 & 1.08 & 1.24 & 1.35 & 1.35 & 1.25 \\
\hline AY+A.M & 1.20 & 1.25 & 1.35 & 1.41 & 1.30 & 1.04 & 1.28 & 1.44 & 1.39 & 1.29 \\
\hline M.A+A.M & 1.24 & 1.30 & 1.51 & 1.47 & 1.38 & 1.10 & 1.32 & 1.50 & 1.45 & 1.34 \\
\hline $\mathrm{AY}+\mathrm{M} \cdot \mathrm{A}+\mathrm{A} \cdot \mathrm{M}$ & 1.21 & 1.33 & 1.46 & 1.55 & 1.39 & 1.11 & 1.29 & 1.45 & 1.46 & 1.33 \\
\hline Mean (A) & 1.15 & 1.21 & 1.35 & 1.40 & & 1.06 & 1.22 & 1.39 & 1.39 & \\
\hline LSD $0.05 \%$ & \multicolumn{2}{|c|}{$\mathrm{A}: 0.02$} & B:0.03 & \multicolumn{2}{|c|}{ AB: 0.06} & \multicolumn{2}{|c|}{ A: 0.03} & B:0.03 & \multicolumn{2}{|c|}{ AB: 0.06} \\
\hline
\end{tabular}

Cont. $=$ Untreated plants, $\mathrm{AY}=$ Active yeast, M.A.= Minia Azotein, A.M = Arbescular mycorrhizae.

From the obtained results, it could be discussed as follows: The increment in plant growth traits (stem length, stem diameter. Leaves fresh and dry weights and stem fresh and dry weights) and percentages of $\mathrm{N}, \mathrm{P}$ and $\mathrm{K}$ as a result of using filter mud as organic manures might be due to the positive, physiological and biological roles of organic manure on these traits which were explained by many authors such as, Bohn et al. (1985) who indicated that organic matter as a main source of $\mathrm{N}, \mathrm{P}, \mathrm{S}$ and contains high content of B and Mo and also as source of energy for Azotobacter growth. Saber (1997) reported that organic manure minimize the lost of nutrients by leaching. Organic manure resulted an augment in microbial activities in the root zone when applied it to the soil (Taiwo et al., 2002). 
The enhancement in the previous parameters due to biofertilizers application could be attributed to the biological and physiological roles of these inoculants. Minia Azotein (contains Nfixing bacteria), Many investigators for example (Dadarwell et al., 1997; Hauwaka, 2000 and Hedge et al., 1999) explored $\mathrm{N}$-fixing bacteria rolesas as follows: Fixing atomospheric $\mathrm{N}$ which causes enhancing available $\mathrm{N}$ that increase, consequently the formation of many metabolites, producing adequate photohormones (IAA, GA3 and cytokinins). Increasing different nutrients uptake and enhancing water status which causes an increase in meristematic activities of cell and tissues, consequently augment plant growth protecting their host plants against plant pathogens through production of antibacterial and antifungal substances. Mycorrhizal fungi acts an important roles on plant growth and productivity as follows: Acting as root hairs of plants which led to increasing absorptive area and acts as extension to the root system. Phosphate dissolving organisms including mycorrhizal fungi are capable to produce some growth stimulation substances (auxins, GA3 and cytokinins). Enhancing the roots to secretion of organic acids and $\mathrm{CO} 2$ which lead to increase the solubility of phosphate production of phosphate enzymes that are capable to converting organic phosphate to mineral $\mathrm{P}$ which it is possible to absorb by the plants. promotion on elements absorption $(\mathrm{N}, \mathrm{S}$, $\mathrm{Ca}, \mathrm{Zn}, \mathrm{Mn}$ and $\mathrm{Cu}$ ). Increment in the resistance of inoculant plants to the stress due to nutrients deficiency and drought, protecting the plants from some diseases and increasing the immunity against the diseases via increasing the thickness of root cortex (Read et al., 1991; Tate, 2001). Active yeast plays an important rol in enhancing the growth and chemical constituents, Tarrow and Nakase (1975) and Subbo Rao (1984) concluded that active dry yeast contains high amounts of four vitamins, particularly $B$ that acts an important role in enhancing the growth and controlling the incidence of fungi diseases. From the revealed results, it could be recommended to supply the soil of Taxodium distichum seedlings with filter mud at $72 \mathrm{~g} /$ plant and treating the seedlings with mixture of biofertilizers (Minia Azotein + mycorrhizal fungi + active dry yeast) to improve the growth and some chemical constituents traits under the investigation conditions.

\section{References}

Abdel- Salam, O. R. (2017), Effect of some agricultural treatments on growth, yield and chemical constituents of moringa seedlings, M.Sc. Thesis, Faculty of Agriculture, Al-Azhar University, Assiut, Egypt.

Abdou, M. A. H. and Ashour, R. M. (2012), Physiological studies on jojoba plants, Minia International Conference for Agriculture and Irrigation in the Nile Basin Countries, Minia, Egypt.

Abdou, M. A. H., Ahmed, E. T. and 
Attia, F. A. (2003), Response of Delonix regia, RAF. transplants to fertilization with sewage sludge and inoculation with phosphorein and VA-mycorrhizal fungi, Proceedings of the $1^{\text {st }}$ Egyptian-Syrian Conference for Agriculture and Food in the Arab world Faculty of Agriculture, University of Minia, Minia, Egypt.

Abdou, M. A. H., Ahmed, E. T., Taha, R. A. and Helmy, S. M. S. (2006), "Response of Khaya senegalensis to some bio and chemical fertilization treatments", Minia Journal of Agriculture Research and Development, Vol. 26 No. 3, pp. 427-448.

Abdou, M. A. H., Attia, F. A. and Ahmed, E. T. (2004), "The response of Albizzia lebbek, L. plants grown in sandy soil under salt stress to Biogein, Genistein and Vapor Gard treatments", Mansoura Journal of Agricultural Science, Vol. 29 No. 2, pp. 799-814.

Abdou, M. A. H., Badran, F. S., Aly, M. K. and Ashour, R. M. (2007), Physiological studies on the propagation of Ficus elastica var. decora by aerial layering, $1^{\text {st }}$ International Conference of Desert Cultivation, Problems \& Solutions, Minia University, Minia, Egypt.

Abdou, M. A. H., Tantawy, A. A. and Taha, R. A. (2008), "Effect of number of irrigations and organic fertilization on jojoba seedlings grown in sandy soils", The First International Conference On Environmental Studies and Research (Natural Resources and Sustainable Development ), El-Hattab Environmental Studies and Research Institute (ESRI), Minufiya University - Sadat Branch, Egypt, pp. 84-93.

Abou El-Khair, K. H. S. (1993), "The role of vesicular arbuscular mycorrhize in growth and mineral contents of Acacia saligna and Casuarina glauca seedlings grown in sandy soil, treated with different levels of phosphorus", Mansoura Journal of Agricultural Science, Vol. 18 No. 5, pp. 1450-1459.

Abou El-Makarem, S. H. E. (2016), Response of moringa plants to some agricultural treatments, Ph.D. Dissertation, Faculty of Agriculture, Minia University, Egypt.

Ahmadloo, F., Tabari, M., Yousefzadeh, H., Kooch, Y. and Rahmani, A. (2012), "Effects of soil nutrient on seedling performance of Arizona cypress and medite cypress", Annals of Biological Research, Vol. 3 No. 3, pp. 1369-1380.

Ahmed, A. A. (2002), "Study the effect of addition methods and concentration of active dry yeast on the growth and chemical composition of Leucaena leucocephala", Proceedings of Minia $1^{\text {st }}$ Conference for Agriculture and Environmental Science, Minia, 
Egypt, pp. 367-376.

Ahmed, A. A. and Ali, A. F. (2002), Effect of some bio-fertilizers on growth and chemical composition of two woody tree seedlings grown in sandy calcareous soil, Proceedings of Minia $1^{\text {st }}$ Conference for Agriculture and Environmental Science, Minia, Egypt. p. 419-429.

Ahmed, A. A., Ali, A. F. and Dakhly, O. F. (2005), Response of Populus nigra seedlings to Azotobacter vinelandii trans formant isolates and nitrogen fertilization, The $6^{\text {th }}$ Arabian Conference for Horticulture, Ismailia, Egypt, pp. 138-150.

Ahmed, A. A., Ali, A. F. and Taha, R. A. (2006), "A comparative study between two poplar species grown in sandy calcareous soils using certain compost levels", Minia Journal of Agriculture Research and Development, Vol. 26 No. 4, pp. 663-681.

Ahmed, F. F., Akl, A. M., El-Morsy, F. M. and Ragab, M.A. (1997), "The beneficial effect of bio-fertilizer on Red Roomy grape vines (Vitis vinfera, $L$.): 1-The effect on growth and vine nutritional status", Annals of Agric Science. Moshtohor, Vol. 35 No. 1, pp. 489-495.

Ahmed, R. F. (2014), Effect of some growth media, bio-fertilization and antioxidants on Ceiba pentandra, $L$. tree seedlings, Ph.D. Thesis, Faculty of Agriculture, Minia University, Minia, Egypt.

Ahmed, S. K., Ali, A. F. and Khater, M.

R. (2001), Effect of salinity treatments and active dry yeast on growth and active ingredients of Ambrosia maritima L., The fifth Arabian Horticulture Conference, Ismailia, Egypt, pp. 217-224.

Ahmed, S. K., El-Ghawas, E. O. and Ali, A. F. (1998), "Effect of active dry yeast and organic manure on roselle plant", Egyptian Journal of Agricultural Research, Vol. 76 No. 3, pp.1115-1142.

Akl, A. M., Ahmed, F. F., EI-Morsy, F. M. and Ragab, M. A. (1997), "The beneficial effect of bio-fertilizer on Red Roomy grape vine (Vitis vinifera L.): 2-The effect on berry set, yield and quality of berrers", Annals of Agricultural Science Moshtohor Journal, Vol. 45 No. 1, pp. 497-502.

Alaa El-Din, M. M. (1982), "Biofertilizers -requirements and application", FAO Soils Bulletin, Vol. 45, pp. 164-174

Al-Hadad, Z., Soliman, A., Morsy, E., Kamel, S. and El-Sayed, A. A. (2014), "Effect of different biofertilizers and soil media on growth and chemical composition of Eucalyptus camaldulensis in North Africa", Journal of Horticulture Science and Ornamental Plants, Vol. 6 No. 2, pp. 59-70. 
Ali, A. F. (2001), Response of pot Marigold (Calendula officinalis, L.) plants to some rock phosphate sources and yeast, The Fifth Arabian Horticulture Conference, Ismailia, Egypt, pp. 30-42.

Ali, A. F., Ahmed, A. A. and ElMorshedy, M. M. (2001), "Effect of some organic manure on vegetative growth and chemical composition of Khaya senegalensis, A. Juss seedlings grown in different soil types", The Fifth Arabian Horticulture Conference, Ismailia, Egypt, pp. 17-29.

Ali, A. F., Ahmed, A. A. and Mahmoud, M. R. (2002), Response of Populus nigra seedlings grown in sandy calcareous soil to some organic fertilizers and nitrogen level treatments, Minia $1^{\text {st }}$ Conference for Agriculture and Environmental Science, Minia, Egypt, pp. 377-392.

Ali, A. F., Hassan, E. A., Ahmed, A. A. and Abd El-Raheem, A. S. H. (2015), "The importance of using Minia Azotein and some micronutrients in improving the growth and chemical constituents of Khaya senegalensis seedlings", Journal of Biological Chemistry Environmental Science, Vol. 10 No. 1, pp. 127-141.

Ali, A. F., Hassan, E.A., Hamad, E.H. and Ibrahim, M.F. (2014), "Response of Cassia acutifolia plants to some fertilization treatments", Journal of Biological
Chemistry Environmental Science, Vol. 9 No. 1, pp. 561-583.

Allen, J. A., Pezcshki, S. I. T. and Chambers, J. L. (1996), "Interaction a flooding and salinity Bald cypress (Taxodium diszichum)", Tree Physiology, Vol. 16, pp. 307-313.

Badr El-Din, S. M. S, Attia, M. and AboSedera, S. A. (1999), "Evaluation of several substrates for mass multiplication of Arbuscular mycorhizal (AM) fungi grown on onion", Egyptian Journal of Microbiology, Vol. 34, pp. 57-61

Badran, F. S., Abdou, M. A., Aly, M. K., Sharaf El-Deen, M. N. and Mohamed, S. H. (2003), Response of sandy soil grown Acacia saligna seedlings to organic bio- and chemical fertilization and IAA treatments, $1^{\text {st }} \quad$ Egyptian-Syrian Conference in Agriculture and Food in the Arabian Nation, Minia University, Minia, Egypt, pp. 8-11.

Black, C. A., Evans, D. D., Ersminger, L. E., White, J. L. and Clark, F. E. (1965), Methods of Soils Analysis, American Society of Agronomy, Inc., Bulletin, Madison, Wisconsin, USA, pp. 891-1440.

Bohn, H. L., Meneal, B. L. and Connar, G. A. O. (1985), "Soil Chemistry $2^{\text {nd }}$ ed., Awiley Interscience Publication John Wiley and Sons, New York, USA.

Chapman, H. D. and Pratt, P. F. (1975), 
"Methods of Analysis for Soil", Plant and Waters, Division of Agriculture and Natural Resources, University of California, USA, pp. $17-172$.

Collingwood, G. H. (1937), Knowing your trees, The American Forestry Association, Washington, DC, USA.

Cottenie, A., Verloo, M., Velghe, M. and Camerlynck, R. (1982), Chemical Analysis of Plant and Soil, Laboratory of Analytical and Ayro Chemistry, State Universitycof Ghent, Belgium.

Dadarwall, L. R., Yadv, L. S. and Sindhu, S. S. (1997), Bio-fertilizer production: Technology: Prospects in biotechnological approach in soil microorganisms for sustainable crop production. Scientific Publishers, Jodhpur, India, pp. 323-337.

Dash, S., Mohapatra, A. K. and Gupta, N. (2013), "Growth response of Dalbergia sissoo Roxb. to mineral solubilizing bacteria and fungi in nursery conditions", Tropical Ecology, Vol. 54 No. 1, pp. 109115.

EI-Tantawy, M. E., EI Sakhawy, F. S., EI Sohly, M. A. and Ross, S. A. (1999), "Chemical Composition and Biological Activity of the Essential Oil of the Fruit of Taxodium distichum L. Rich Growing in Egypt", Journal of Essential Oil Research, Vol. 11 No. 3, pp. 386392.
El-Khateeb, M. A., El-Madaawy, E. and El-Attar, A. (2010), "Effect of some bio-fertilizers on growth and chemical composition of Chamaedorea elegans Mart seedlings", Journal of Horticulture Science and Ornamental Plants, Vol. 2 No. 3, pp. 123-129.

El-Khateeb, M. A., El-Madaawy, E. E. and El Attar, A. B. (2006), "Effect of growing media on growth and chemical composition of Ficus alii, plants", Annals of Agricultural Science Moshtohor Journal, Vol. 44 No.1, pp. 175-193.

El-Sayed, A. A. and Abdou, M. A. H. (2002), "Response of Khaya transplants to some soil media and bio-fertilization treatment", Annals of Agricultural Science Moshtohor Journal, Vol. 40 No. 4, pp. 2233 2245.

El-Tayeb, H. F. and El-Sayed, B. A. (2010), "Response of Ficus binnendykii (Miq.) Miq. cv. "AMSTEL QUEEN" transplants to some bio-fertilizers. Mesopotomia", Mesopotamia Journal of Agriculture, Vol. 38 No. 1, pp. 2-8.

Follet, R. H., Murphy, L. S. and Donahue, R. I. (1981), "Fertilizers and Soil Amendments", Prentice Hall Inc., Englewood Cliffs, N.J., USA.

Gomez, K. A. and Gomez A. A. (1984), "Statistical Procedures for Agricultural Research", $2^{\text {nd }}$ Edition, 
John Wily and Sons, New York, USA, $680 \mathrm{pp}$.

Hartmann, A., Singh, A. and Klngmuller, W. (1983), "Isolation of characterization of Azospirillinm mutanis excreting high amount of indole acetic acid", Canadian Journal of Microbiology, Vol. 29, pp. 916-923.

Hauwaka, F. I. A. (2000), "Effect of using single and composite inoculation with Azospirillum brasilense, Bacillus megatherium var. phosphaticum and Glomus marcocarpus for improving growth of Zea mays", Mansoura Journal of Agricultural Science, Vol. 25 No. 1, pp. 239-252.

Hedge, D.M., Dwivedi, B.S. and Sudhakara, B.S.S. (1999), "Biofertilizers for cereal production in India - A review", Indian Journal of Agriculture Research, Vol. 69 No. 2, pp. 73-83.

Hussein, S. H. H. (2019), Effect of some Agricultural treatments on Moringa pregrena plant, Ph.D. Thesis, Faculty of Agriculture, Minia University, Minia, Egypt.

Jackson, M. L. (1973), Soil Chemical Analysis, Englewood Cliffs, New Prentice-Hall Inc., New York, USA.

Larzen, B. S. (1980), "BMd S-tupelo", Forest Cover Types of the United States and Canada, Ed. Eyre F. H., Society of American Foresters,
Washington, D.C., USA, pp. 68.

Mahmmoud, M. A. (2014), Physiological studies on poplar trees, Ph.D. Thesis, Faculty of Agriculture, Minia University, Minia, Egypt.

Meenakshisundaram, M., Santhaguru, K. and Rajenderan, K. (2011), "Effects of bioinoculants on quality seedlings production of Delonix regia in tropical nursery conditions", Asian Journal of Biochemistry and Pharmaceutical Research, Vol. 1 No. 1, pp. 98-107.

Mohan, V. and Radhakrishnan, A. (2012), "Screening of phosphate solubilizing bacterial isolates for the growth improvement of Tectona grandis Linn", Research Journal of Microbiology, Vol. 7 No. 2, pp. 101-113.

Moustafa, H. E. B. (2008), Influence of some growth media, bio-fertilization and antioxidants on the growth of Chorisia speciosa tree seedlings, Ph.D. Thesis, Faculty of Agriculture, Minia University, Minia, Egypt.

MSTAT-C (1986), A microcomputer program for the design management and analysis of agronomic research experiments, Version 4.0, Michigan State University, USA.

Munro, R., Wilson, J., Jefwa, J. and Mbuthia, K. (1999), "A low-cost method of mycorrhizal inoculation improves growth of Acacia tortilis seedlings in the nursery", Forest 
Ecology and Management, Vol. 113 No. 1, pp. 51-56.

Nagodawithana, W. T. (1991), Yeast Technology, Universal Foods Corporation, Milwaukee, Wisconsin, Van Nostrand Reinhold, New York, USA, pp. 273.

Natarajan, K. (2007), Panchagavya for plant, Proceedings of National Conference on Glory of Gomatha, Veterinary University, Tirupati, India, pp. 72-75.

Ndiaye, M., Cavalli, E., Manga, A. and Diop, T. (2011), "Improved Acacia Senegal growth after inoculation with arbuscular mycorrhizal fungi under water deficiency conditions", International Journal of Agriculture and Biology, Vol. 13 No. 2, pp. 271274.

Ndoye, F., Kane, A., Bakhoum, N. and Sanon, A. (2013), "Response of Acacia Senegal (L.) Willd. to inoculation with arbuscular mycorrhizal fungi isolates in sterilized and unsterilized soils in Senegal", Agroforestry Systems, Vol. 87 No. 4, pp. 941-952.

Pindi, P. K. (2011), "Influence of bioinoculants on the growth of Albizia lebbeck in nursery conditions", Research Journal of Agricultural Science, Vol. 2 No. 2, pp. 265-268.

Rao, S. N. S. (1981), Bio-fertilizers in Arabic, Oxford and IBH Publishing
Co., Calcutta, Bombay, New Delhi, India, pp. 6-9, 16-22, 77-92 and 142-160.

Read, D. J., Lewis, D. H., Fitter, A. H. and Alexander, L. J. (1991), Mycorrhizas in ecosystems, British Library, UK.

Saber, M. S. (1997), Bio-fertilized Farming System, Proceeding of the Training Course on Bio-organic Farming Systems for Sustainable Agriculture, Cairo, Egypt, pp. 1672.

Saleh, S. I. I. (2000), "Effect of different planting media on the growth and chemical composition of Ficus benjamina "Starlight" plants grown under two locations "outdoor and plastichouse" conditions, Egyptian Journal of Horticulture, Vol. 27 No.4, pp. 543-568.

Sarr, A., Diop, B., Pelter, R., Neyra, M. and Lesueur, D. (2005), "Effect of Rhizobial inoculation methods and host plant provenances on nodulation and growth of Acacia saligna and Acacia nilotica", New Forests, Vol. 29 No. 1, pp. 75-87.

Sharaf, M. (1928), "An English Arabic Dictionary of Medecine", Biology and Allied Science, Government Press, Cairo, Egypt.

Siraj, M.S., El-Garawany, M. N. and AlGosaibi, A. M. (2001), "Effects of manure extracts on soil mineral content and rooting and shooting of 
Ficus benjamina", The Fifth Arabian Horticulture Conference, Ismailia, Egypt, p. 127-132.

Soliman, A.S.h., Morsy, E.M. and Massoud, O.N. (2015), "Tolerance of bio-fertilized Delonix regia seedlings to irrigation intervals", Journal of Horticulture and Forestry, 7(3): 73-83.

Sreenivasa, M. N., Nagaraj, M. N. and Bhat, S. N. (2010), "Beejamruth: A source for beneficial bacteria, Kamataka", Journal of Agricultural Science, Vol. 17, pp. 72-77.

Subba Rao, N. S. (1984), "Bio-fertilizers in Agriculture Oxford IBH. Company. New Delhi.

Sudhakar, P., Chattopadhyay, G.N., Gangwar, S.K. and Ghosh, J.K. (2000), "Effect of Azotobacter biofertilizer with inorganic nitrogen on leaf yield and quality of mulberry (Morus alba)", Tropical Science, Vol. 40 No. 2, pp. 75-82.

Taiwo, L. B., Adediran, J. A., Ashaye, O. A., Odofin, O. and Oyadoyin, A. J. (2002), "Organic Okra (Abolmoschus esculantus): its growth, yield and organoleptic properties", Nutrition and Food Science, Vol. 32 No. 415, pp. 180183.

Tarrow, D. and Nakase, A. (1975), "DNA bas composition of spaces of the genus saccharomyces", Antonie van Leeuwenhoek, Vol. 41, pp. 81.
Tate, R. L. (2001), Soil microbiology, Secord edition, John Wiley \& Sons Inc., USA, pp. 375-394.

Tien T. M., Gaskns, M. H. and Hubbell, D. H. (1979), "Plant growth substances produced by Azosprilum brasilense and their effect on the growth of pearl millet (Pennisetum americanum L)", Applied and Environmental Microbiology, Vol. 37, pp. 1016-1024.

Walker, L. C. (1990), "Forests A Naturalist's Guide to Trees and Forest Ecology, 288, John Wiley and Sons Inc., New York.

Wilde, S. A., Corey, R. P., Lyer, J. C. and Voigt, G. K. (1985), Soil and Plant Analysis for Tree Culture, Oxford IBH. Publishing Co. New Delhi, India.

Wilhitc, L. P. and Toliver, J. I. T. (1990), Taxodiuin distichzim (L) Rich. Baldcypress, USDA Forest Service, Agriculture Handbook 654, Washington. DC, USA, pp. 563. 